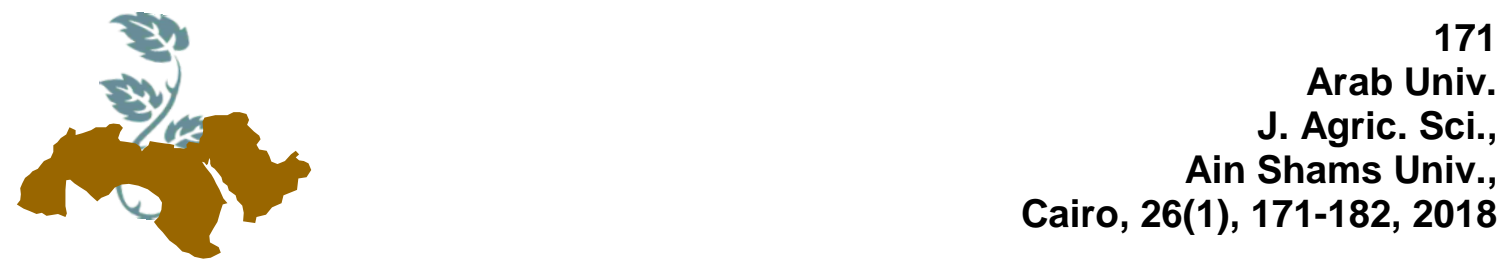

\title{
PERFORMACE EVALUATION OF SOLAR PHOTOVOLTAIC PUMP FOR OPERATING OF LANDSCAPE SYSTEM
}

\author{
Swidan, B.M. and M.M. Mostafa \\ Agric. Eng. Dept., Fac. of Agric., Ain Shams Univ., Cairo, Egypt
}

Keywords: Solar water pumping; Pumping system; Photovoltaic water pumping; landscape; Performance evaluation

\begin{abstract}
Most landscapes requires the water essentially, water pumping consumes a significant amount energy. The study carried out to evaluate the performance of a solar water pumping system for the purpose of operating landscape system. The system consists of a centrifugal water pump connected directly to DC electric motor that which connected directly to a solar photovoltaic generator. Field test had been carried out at Menofia Governorate, Egypt. Measurements were taken every hour starting from 8:00 AM to 4:00 PM through randomly selected days during the period between August 2016 and February 2017. Results show the relation between the solar radiation and the output electrical power, hydraulic power, pumping rates and the efficiency of the system. System evaluation was carried out by estimating the intensity of solar radiation, Photovoltaic output power and the hydraulic power generated. The PV output power was $712 \mathrm{~W}$ at solar radiation intensity of $841 \mathrm{~W} / \mathrm{m}^{2}$. Also, photovoltaic generator and pumping system efficiencies were $14.98 \%$ and $14.21 \%$ respectively.
\end{abstract}

\section{INTRODUCTION}

The world is witnessing in the current period, an increase in the steady population growth and a marked rise in the levels of culture, urbanization and luxury living. Thus, the horizontal expansion of the building industry becomes the element that meets the needs and must be done to urban planning standards, green spaces and public spaces in size up to $80 \%$ of the total area of the layout. Most landscapes depends on water essentially, whether used in the water features such as fountains, wa- terfalls and pools or irrigate plants and even in the hydration and reduce air temperature. The presence of water in the landscape like plants is of the most important elements that brings life to the landscape.

Water pumping consumes a significant amount of the electricity of the national grid and diesel fuel. On the other hand, Egypt currently faces an energy crisis due to the growing energy demand, in addition to fluctuating and increasing costs of energy derived from fossil fuels. It is important to find ways of decreasing dependency on fossil fuels. The utilization of solar energy is good choice to face the energy crisis Gawdat (2013).

Solar radiation on Egypt ranges from 5 to 8 $\mathrm{kWh} / \mathrm{m}^{2}$ per day with about 3500 sunshine hours per year, (Sorensen, 2003). Solar water pumping may be a competitive application for remote areas and luxurious areas where power costs a lot. (Kaldellis et al 2011).

Nowadays, the utilization of PV conversion of solar energy to power the water pumps is an emerging technology with great challenges. The PV technology can be applied on a larger scale and it also presents an environmentally favorable alternative to diesel fuel and grid electricity as a power source for water pumps, (Kumar et al 2010 and Mittal et al 2012).

Solar photovoltaic water pumping systems (SPVWPS) providing domestic, livestock and irrigation water supplies in remote areas have gained enormously in acceptance, reliability and performance. Installing SPVWPS has many advantages to the pumping sites, where the national electricity grid connection is not available, solar energy is available abundantly, and the transport facilities are not good enough (Ghoneim, 2006).

Furthermore, the use of solar photovoltaic power to operate the water pumping system is the most appropriate choice because there is a natural 
relationship between requirement of water and the availability of solar power (Hsieh, 1986).

The solar energy systems are devices convert the solar radiation into other forms of energy. They can be divided into thermal effect and photo effect (non-thermal) systems, (Yüncü et al 2012).

The non-thermal solar systems or the solar photovoltaic cells (PVCs) directly convert sunlight into electricity which can be captured in the form of a direct electric current. This electricity can be used to power an appliance. The solar panels are therefore effective only during daylight hours and batteries will have to be utilized to provide an electricity supply at other times, (Carrasco et al 2006 and Liserre et al 2010).

In this respect a solar pumping system was tested to evaluate its performance under local working conditions.

\section{The objectives of this research are}

- Use of photovoltaic to operate water pumping system for landscape.

- Study the factors that affect the PV pumping system.

- Evaluate the system performance.

\section{MATERIALS AND METHODS}

The constructed system comprised of three stages; first stage was generating DC power from PV cells, second stage was converting DC power into mechanical power using DC motor and third stage was converting mechanical power into hydraulic power using centrifugal pump.

Fig. (1) Shows the constructed system, which is designed to work in daylight hours only without the use of inverters (AC/DC) or battery banks for the storage of electricity. The system consists of the following elements

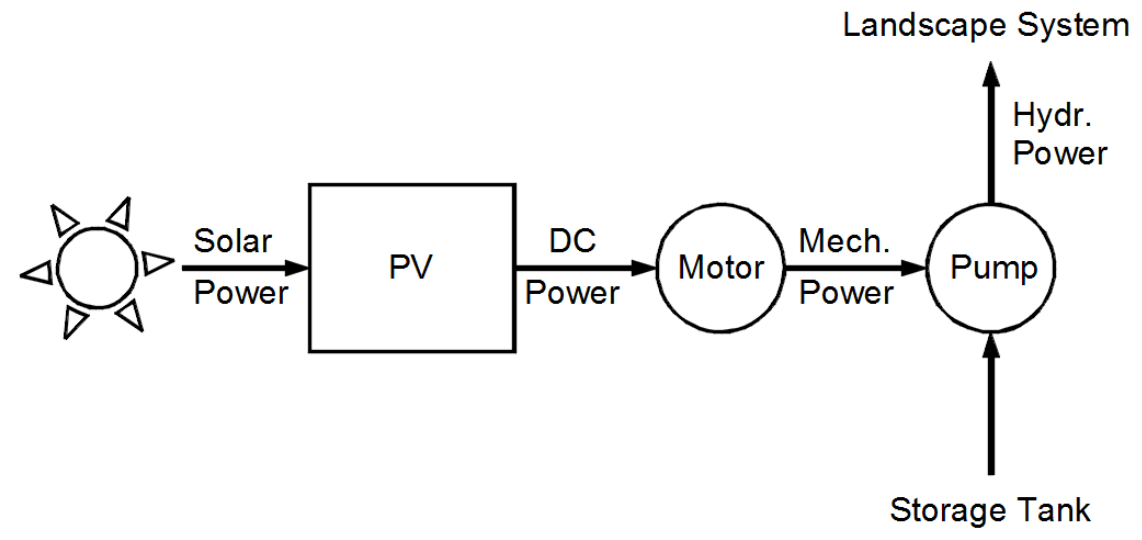

Fig. 1 Components of solar pumping systems and energy conversion steps.

\section{Photovoltaic generator (PV)}

The basic photovoltaic module are presented in Tables 1, 2 and 3

Table 1. Basic photovoeltaic module data

\begin{tabular}{|lc|}
\hline \multicolumn{1}{|c|}{ Model } & Aleo P18 \\
\hline Length $\mathbf{x}$ width $\mathbf{x}$ height [mm] & $1660 \times 990 \times 35$ \\
Weight [kg] & 19 \\
Number of cells & 60 \\
Cell Size [mm] & $156 \times 156$ \\
Cell material & Polycrystalline Si \\
Front sheet & Solar glass (ISG) \\
Back sheet & Polymer sheet, white \\
Frame material & Al alloy, silver \\
\hline
\end{tabular}

Table 2. Photovoltaic module electrical data (STC)

\begin{tabular}{|cccc|}
\hline Rated power & PMPP & {$[\mathrm{W}]$} & 260 \\
Rated voltage & UMPP & {$[\mathrm{V}]$} & 30.5 \\
Rated Current & IMPP & {$[\mathrm{A}]$} & 8.51 \\
Open circuit voltage & Uoc & {$[\mathrm{V}]$} & 37.7 \\
Short circuit current & Isc & {$[\mathrm{A}]$} & 9.01 \\
Efficiency & $\mathrm{n}$ & {$[\%]$} & 15.8 \\
\hline
\end{tabular}

Electrical values measured under standard test conditions (STC): irradiance $1000 \mathrm{~W} / \mathrm{m}^{2}$, module temperature $25^{\circ} \mathrm{C}$, air mass $=1.5 \mathrm{G}$ 
of landscape system

Table 3. Photovoltaic module electrical data (NOCT).

\begin{tabular}{|lccc|}
\hline Power & PMPP & {$[\mathrm{W}]$} & 190 \\
Voltage & UMPP & {$[\mathrm{V}]$} & 27.6 \\
Current & IMPP & {$[\mathrm{A}]$} & 6.89 \\
Open circuit voltage & Uoc & {$[\mathrm{V}$} & 34.6 \\
Short circuit current & Isc & {$[\mathrm{A}]$} & 7.33 \\
Efficiency & $\mathrm{n}$ & {$[\%]$} & 14.5 \\
\hline
\end{tabular}

- DC powered motor;

Voltage: $180 \mathrm{v}$ (operates between 20 and 220V.DC), Max. Speed: 3800RPM and Max.

Power: 2.5HP.

- Centrifugal pump;

Characteristics of the water pump are presented in Table (4).

Table 4 Characteristics of the water pump:

\begin{tabular}{|ll|}
\hline Parameter & Value \\
Q. $\min$ & $5 \mathrm{l} / \mathrm{min}$ \\
Q. $\max$ & $30 \mathrm{I} / \mathrm{min}$ \\
H. $\max$ & $25 \mathrm{~m}$ \\
RPM & 2860 \\
\hline
\end{tabular}

\section{Water storage tank;}

The tank of water storage has dimensions of 30 $\mathrm{cm}$ width, $30 \mathrm{~cm}$ length and $50 \mathrm{~cm}$ height.

The photovoltaic system was implemented consists of four modules $260 \mathrm{~W}$ each, manufacturer ALEO, model P18 polycrystalline. PV array were installed with tilt angle $30^{\circ}$ from the horizontal and faces the south direction. Panels are connected in parallel to give a $7.33 \mathrm{~A}$ and $138.4 \mathrm{~V}$ total to generate power for running DC motor pump system. The photovoltaic modules were installed on a rigid and fixed metal structure on the roof of two floor building. The site was chosen because of the proximity to the water source and because it did not present trees or structures that could provide shade on the photovoltaic cells and damaging the performance. There was a greater concern with the positioning of the panels in relation to their alignment with the geographical north because its incorrect positioning can lead to a decrease in the efficiency of the photovoltaic system.

Permanent magnet DC Motor of a treadmill was used to convert electrical power form the photovoltaic panels into mechanical power to drive the centrifugal water pump. AC motor equipped water pump manufacturer EMC, was engaged to the system by connecting its shaft to the DC motor shaft using a coupling and fixed on one base. The technical specifications of the DC motor are: Voltage: 180V (operates between 20 and 220V DC), maximum speed: $3800 \mathrm{rpm}$ and maximum power: 2.5HP. The technical specifications of the water pump are Q.min.:5 I/min, Q.max.:30 l/min, H. max.: $25 \mathrm{~m}$ and $2860 \mathrm{rpm}$.

The water tank was used as a reservoir of water, where it is providing the pump inlet with water and in the same time containing water from out stream, so that the system was working as a closed cycle of water to save water.

Measuring instruments were used to obtain data of the following parameters:

- The output voltage and current from the photovoltaic panels by digital electrical multimeter;

- Water flow rate from the pump by electronic flow meter;

- Water pressure from the pump by analog pressure gage;

- Ambient air temperature behind the PV array by digital thermometer.

- Data were collected for 7 months, beginning on August 24, 2016, till $12^{\text {th }}$ of February, 2017, when the readings were performed every $1 \mathrm{~h}$.

Measurements were performed in order to evaluate the performance of photovoltaic solar pumping system and PV efficiency under conditions of different parameters affecting the performance. In order to study the energy conversion from solar radiation to water flow, the following six equations were used according to both Hamza and Taha (1995).

\section{The Input Power (Pi)}

The incident solar radiation to the PV array gives the input power $(\mathrm{Pi})$ to the system:

$$
\begin{aligned}
& \text { Where: } \\
& \quad \mathbf{P i}=\mathbf{G} \times \mathbf{A} \quad(\mathbf{W}) \\
& \quad \begin{array}{l}
\text { G } \\
\text { solar radiation }\left(\mathrm{W} / \mathrm{m}^{2}\right) \\
\text { module cell area }\left(\mathrm{m}^{2}\right) .
\end{array} \text { and } A=\text { effective }
\end{aligned}
$$

\section{PV Array Output (Po)}

The DC output power (Po) from the PV array is given by:

$$
\mathrm{Po}=V \times I \quad(\mathrm{~W}) \quad-------(2)
$$


Where: $\mathrm{V}$ = operating voltage $(\mathrm{V})$ and $\mathrm{I}=$ operating current $(A)$.

\section{Hydraulic Power Output (Ph)}

Hydraulic power output of the pump (Ph) is the power required to lift a volume of water through a given head

$$
P h=d \times g \times Q \times H \quad(W) \quad-
$$

Where:

$\mathrm{d}=$ water density $\left(\mathrm{kg} / \mathrm{m}^{3}\right), \mathrm{g}=$ specific gravity $\left(\mathrm{m} / \mathrm{s}^{2}\right), \mathrm{Q}=$ water discharge $\left(\mathrm{m}^{3} / \mathrm{s}\right)$ and $\mathrm{H}=$ total pumping head $(\mathrm{m})$.

\section{Array efficiency $\left(\eta_{a}\right)$}

Array efficiency $\left(\eta_{a}\right)$ is the measure of how efficient the PV array is in converting sunlight to electricity:

$$
\eta_{\mathrm{a}}=\mathrm{Po} / \mathrm{Pi} \text { x } 100
$$

\section{Subsystem Efficiency $\left(\eta_{s}\right)$}

Subsystem efficiency $\left(\eta_{s}\right)$ is the efficiency of the entire system components (motor and pump):

$$
\eta_{s}=P h / P o x 100
$$

\section{Overall efficiency $\left(\eta_{\mathrm{o}}\right)$}

Overall efficiency $\left(\eta_{0}\right)$ indicates how efficiently the overall system converts solar radiation into water delivery at a given head:

$$
\eta_{\mathrm{o}}=\mathrm{Ph}, \mathrm{Pi} \times 100 \text { or } \eta_{\mathrm{o}}=\eta_{\mathrm{a}} \times \eta_{\mathrm{s}}
$$

\section{RESULTS AND DISCUSSIONS}

\section{The Input Power}

During the test period of this photovoltaic pumping system (August, 2016 - February, 2017), solar radiation ranged between 0 to 5390 $\mathrm{W} / \mathrm{m}^{2} /$ day on the plane of the PV modules. Fig. (2) shows hourly average incident solar radiation. The maximum value of the solar radiation was 841.88 $\mathrm{w} / \mathrm{m}^{2}$ at $12: 00 \mathrm{pm}$.

The incident solar radiation to the PV array gives the input power $(\mathrm{Pi})$ to the system. The maximum value of input power to the system was $4917.118 \mathrm{w} / \mathrm{m}^{2} /$ day at $12: 00 \mathrm{pm}$.

Fig. (3) shows the average input power obtained during the experiment period.

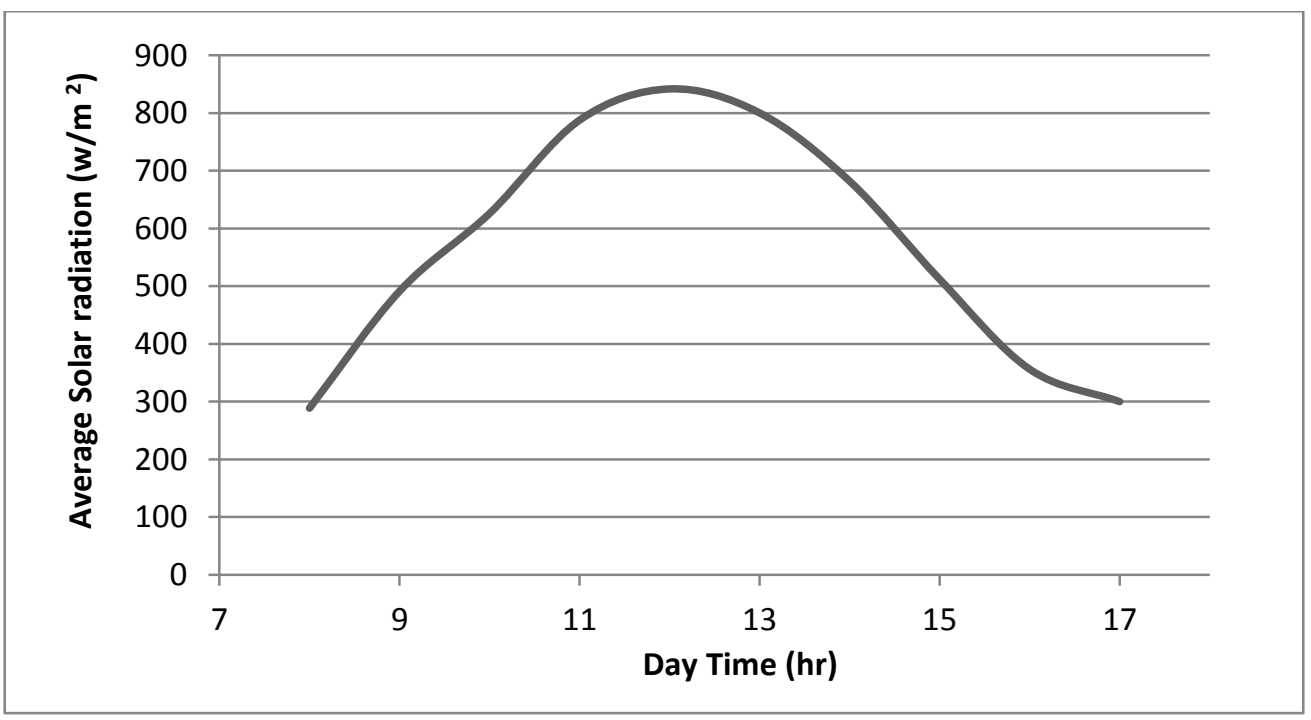

Fig. 2. Daily hourly average solar radiation. 


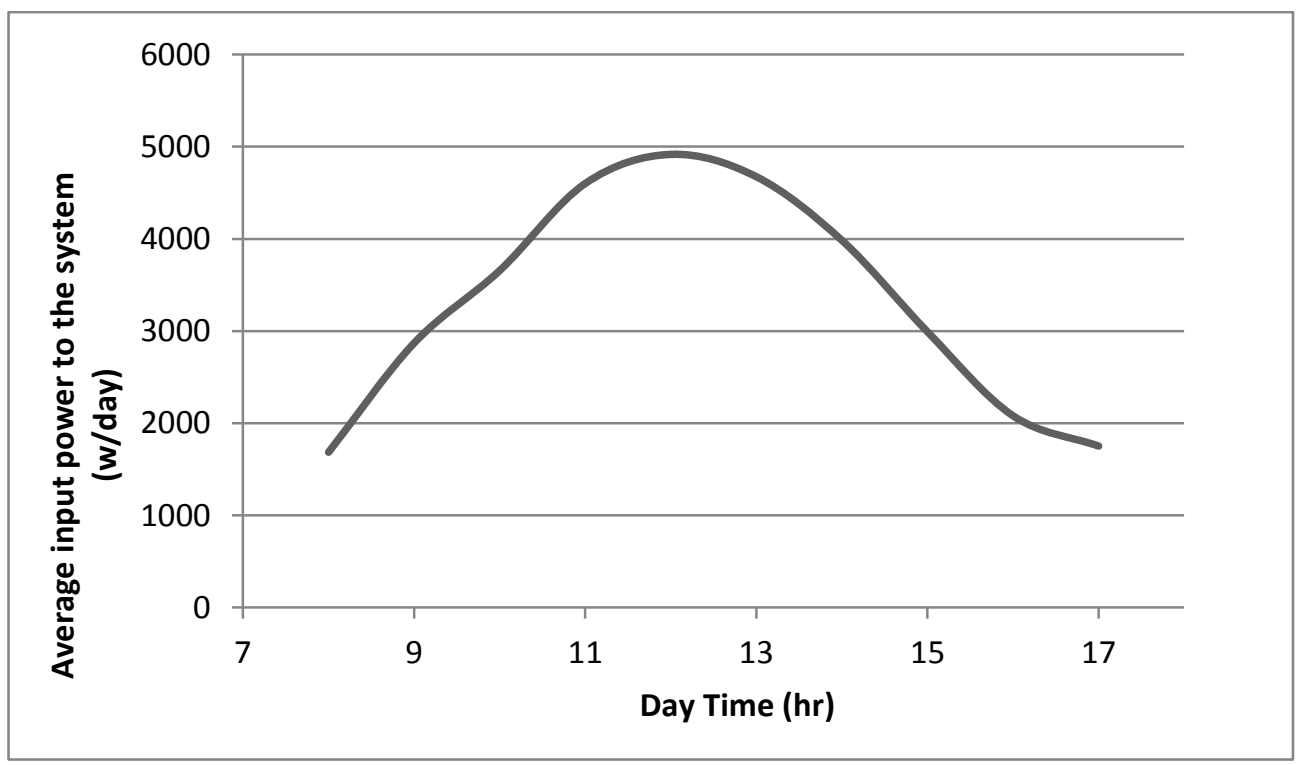

Fig. 3. Average input power to the system (w/day).

\section{PV Array Output}

\section{Generated electric power}

Fig. (4) shows hourly average output power obtained during the experiment period with the incident hourly average solar radiation. The maximum value of solar radiation was $841.88 \mathrm{w} / \mathrm{m}^{2}$ at $12: 00$ $\mathrm{pm}$, while the maximum value of output power was $712.907 \mathrm{w}$ at $12: 00 \mathrm{pm}$.

The results show that output power indicates gradually increase with increasing solar radiation intensity as shown in Fig. (5).

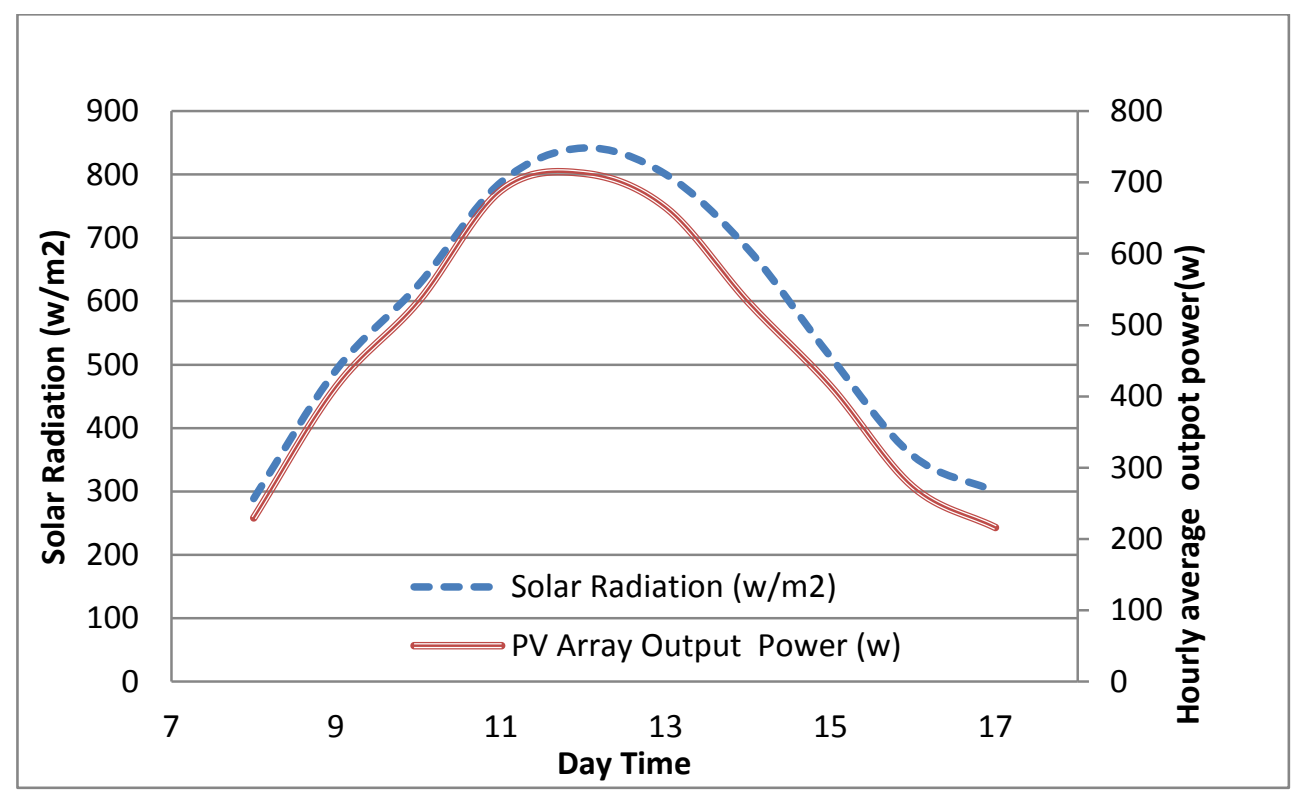

Fig. 4. Daily hourly average PV array output power (W). 


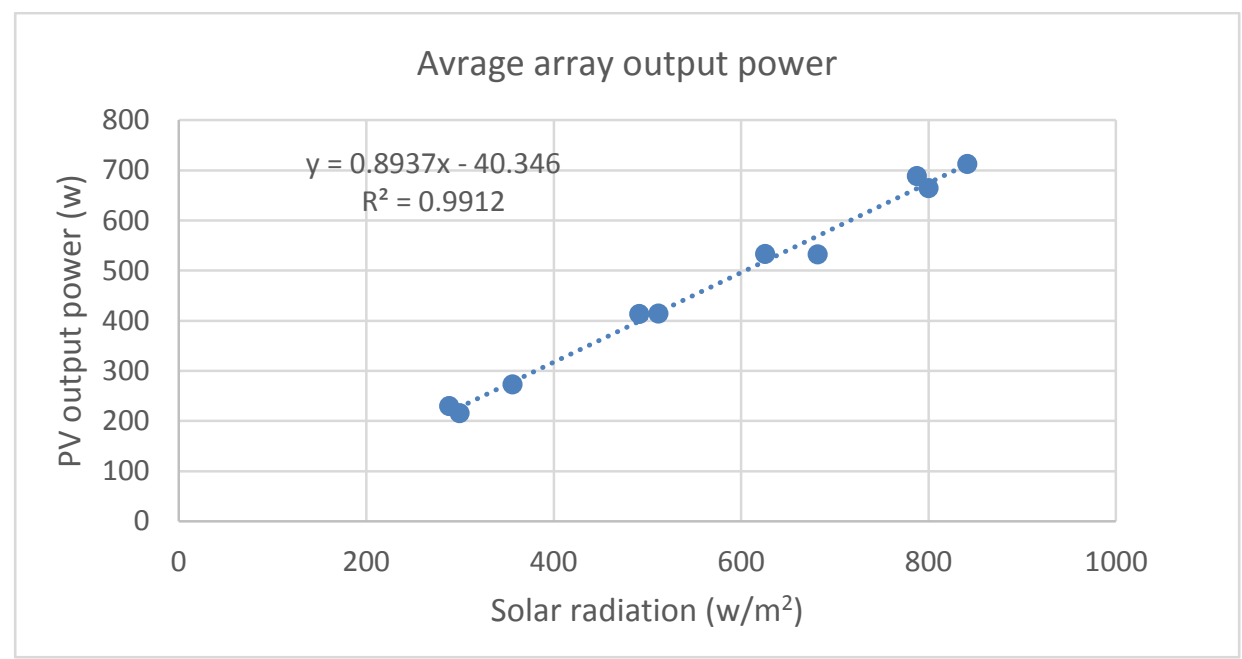

Fig. 5. Daily measured output power as a function of average solar radiation intensity.

\section{Radiation intensity}

Also, the relationship between PV output power and solar radiation was obtained in the following equation:

$$
Y=0.8937 X-40.346
$$

Where:

$\mathrm{Y}=\mathrm{PV}$ output power $(\mathrm{w})$ and $\mathrm{X}=$ Solar radiation $\left(\mathrm{w} / \mathrm{m}^{2}\right)$

\section{Electric power consumption}

Measurements show increase of daily hourly average electric power consumption as a result of the increase of solar radiation as shown in Fig. (6). The highest average power consumption value was found $139 \mathrm{~W}$ which represent the maximum power consumption recorded for the pumping system at 12:00 PM where the average solar radiation found to be $841 \mathrm{~W} / \mathrm{m}^{2}$.

Results also show that the increase of daily hourly average electric power consumption as a result of the increase of PV power output. The highest average power consumption value was found $139 \mathrm{~W}$ which represent the maximum power consumption recorded for the pumping system at 12:00 PM where the average PV output found to be $712 \mathrm{~W}$ as shown in Fig. (7).

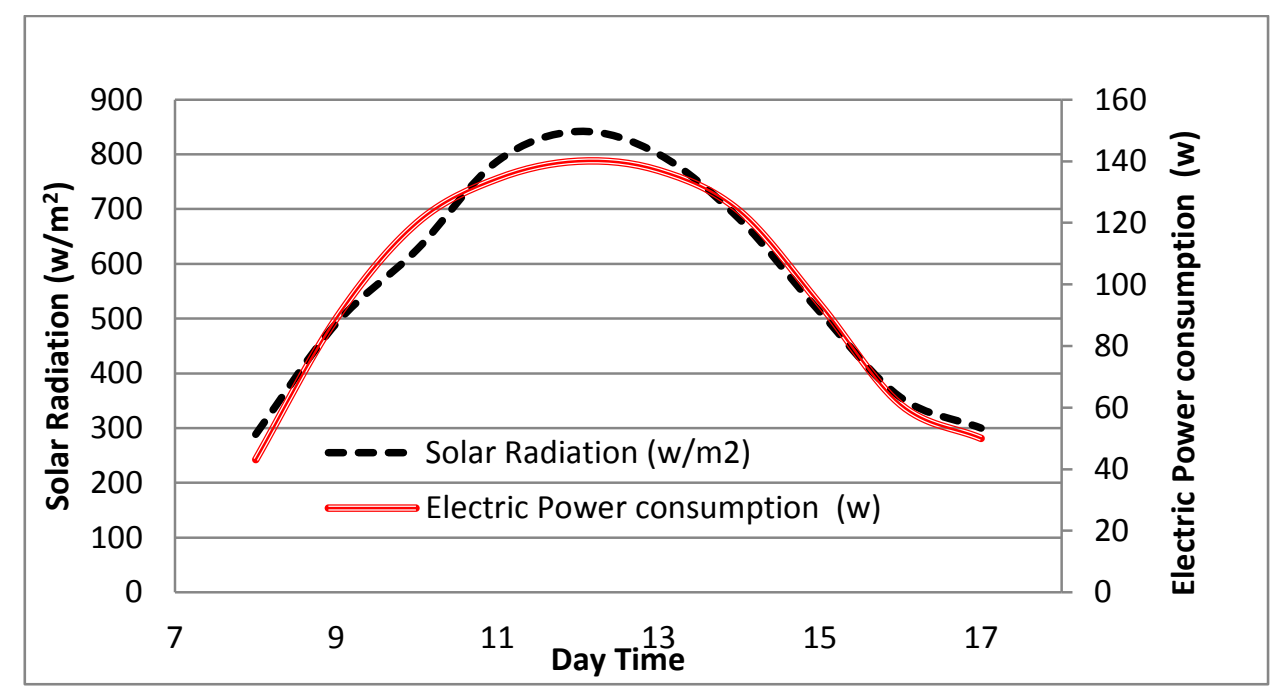

Fig. 6. Hourly average electric power consumption and hourly average solar radiation levels at different day times. 


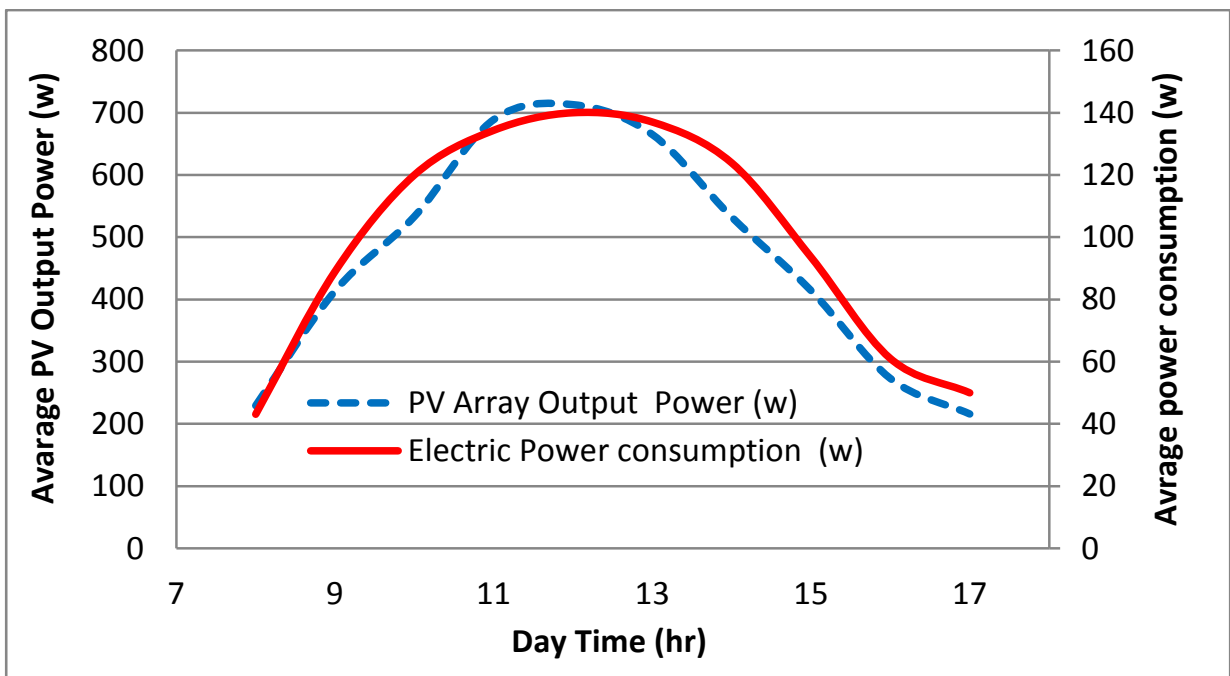

Fig. 7. Hourly average electric power consumption and hourly average output power at different day times.

\section{The hydraulic power output}

The results show that the pumping rate indicate gradually increase with increasing the solar radiation intensity as shown in Fig. (8).

Also, the relationship between average output flow rate and average solar radiation was obtained in as following:

$$
Y=1.0083 x+240.38
$$

Where:

$\mathrm{Y}=$ Hourly average output flow rate (L/hr.) at $5 \mathrm{~m}$ head and $\mathrm{X}=$ Hourly average solar radiation.
Test results shown in Fig. (9) and Fig. (10) indicate that the relation of hourly average pumping rates to the hourly average solar radiation $\left(\mathrm{w} / \mathrm{m}^{2}\right)$ and relevant $\mathrm{PV}$ output power $(w)$. The results show that water delivery by the pump ranged from 450 to 1031 $\mathrm{L} / \mathrm{hr}$. at $5 \mathrm{~m}$ head depending on solar radiation level. The average solar radiation during the test period was $841 \mathrm{w} / \mathrm{m}^{2}$, while the average water delivery was $1031 \mathrm{~L} / \mathrm{hr}$. The hydraulic power output of the pump (Ph) is the power required to lift a volume of water through a given head.

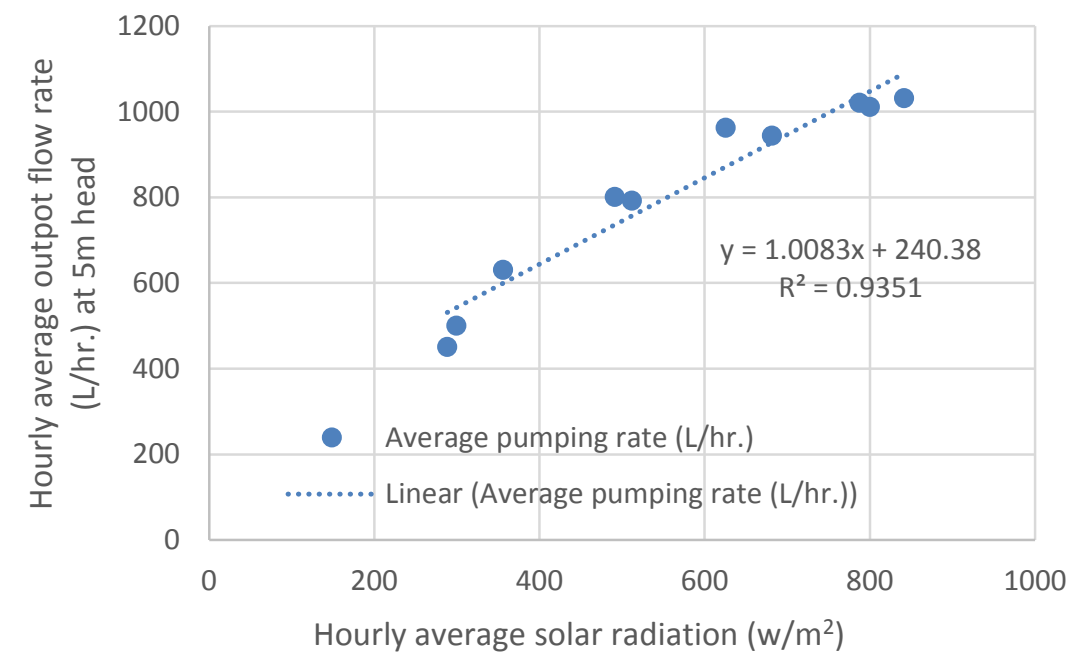

Fig. 8. Pumping rate as a function of solar radiation. 


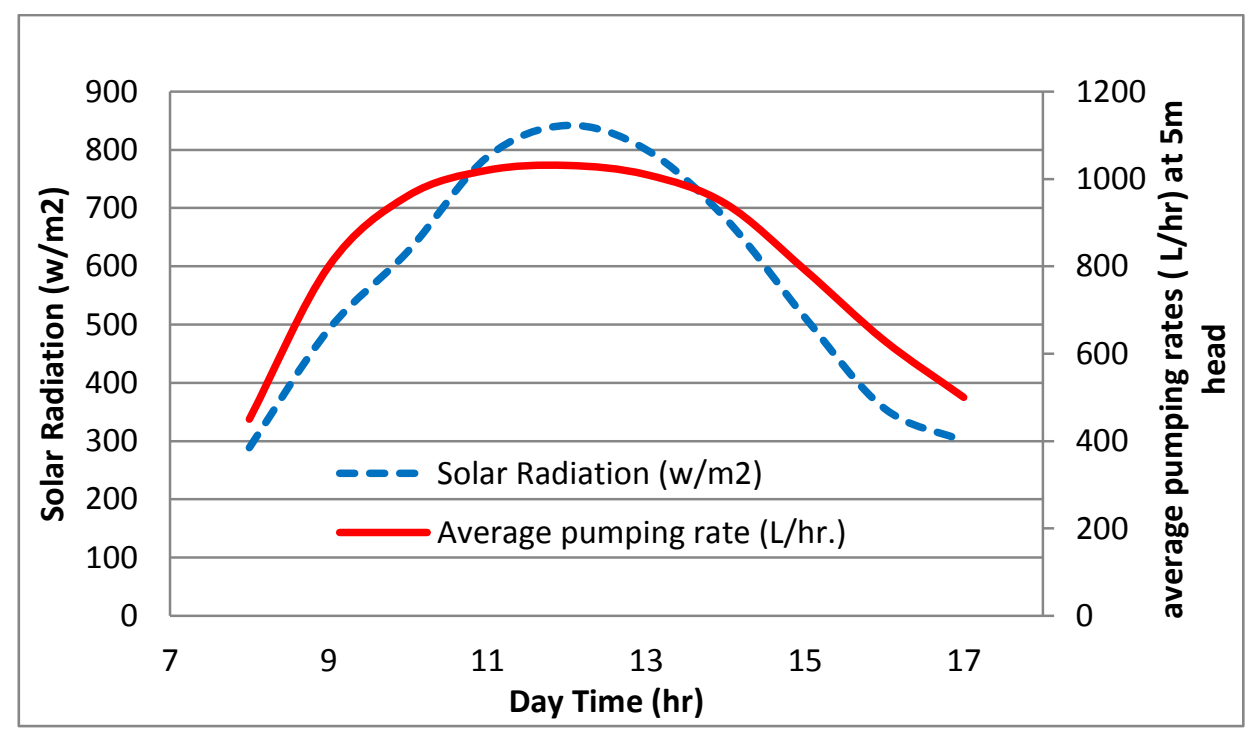

Fig. 9. The variation of radiation intensity caused variation in the measured output pumping rates.

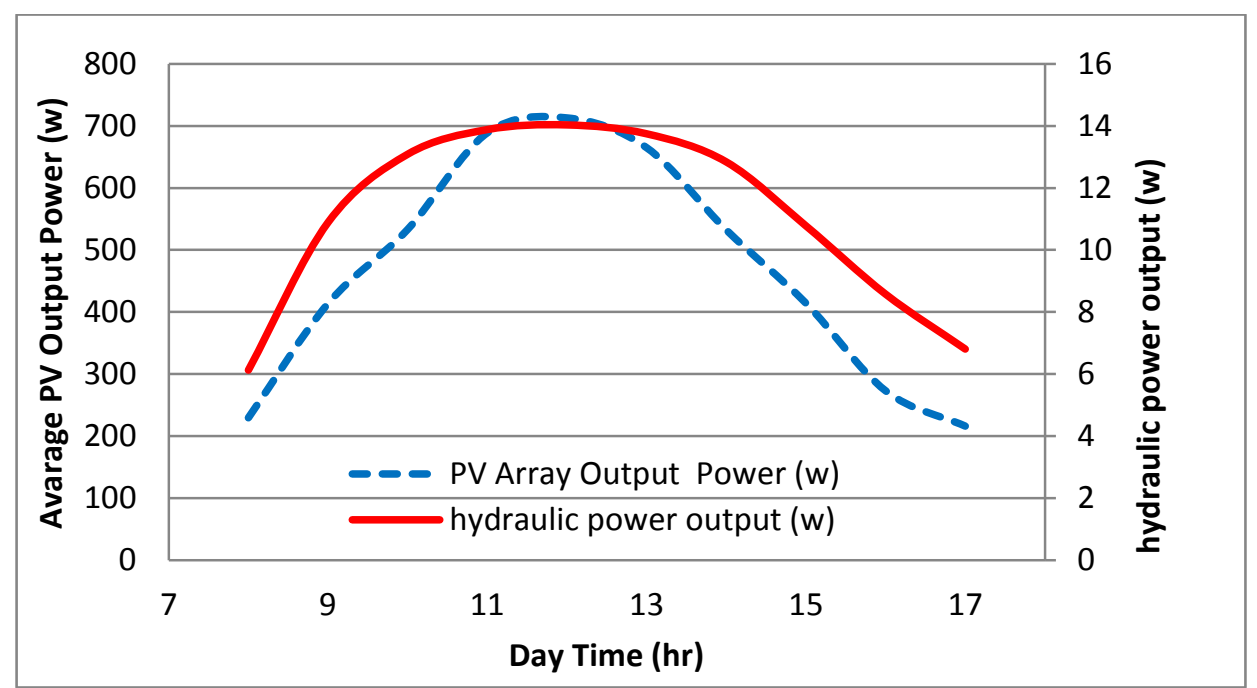

Fig. 10. The variation of radiation intensity and relevant variation in the measured output pumping rates.

\section{Array efficiency}

Results show the gradually increase with increasing solar radiation intensity. Array efficiency average values were ranged between $14.9 \%$ at 11:00 AM and $12.33 \%$ at 5:00 PM The recorded values are in the range of $300 \mathrm{w} / \mathrm{m}^{2}$ at the evening and 841 at 11:00 AM.

Fig. (11) shows array efficiency averages at different values of solar radiation intensity.

The relationship between array efficiency and solar radiation was obtained in as following:

$$
y=3^{*} 10^{-15} x+0.1235
$$

Where:

$\mathrm{Y}=$ Array Efficiency and $\mathrm{X}=$ Solar Radiation $\left(w / m^{2}\right)$.

\section{Subsystem efficiency}

Subsystem efficiency (ns) was calculated considering the input power is the closed circuit power of the system. Pumping system efficiency was measured by calculating electric power consumption and hydraulic power. Fig. (12) shows that pumping system efficiency average at different values of solar radiation intensity. 


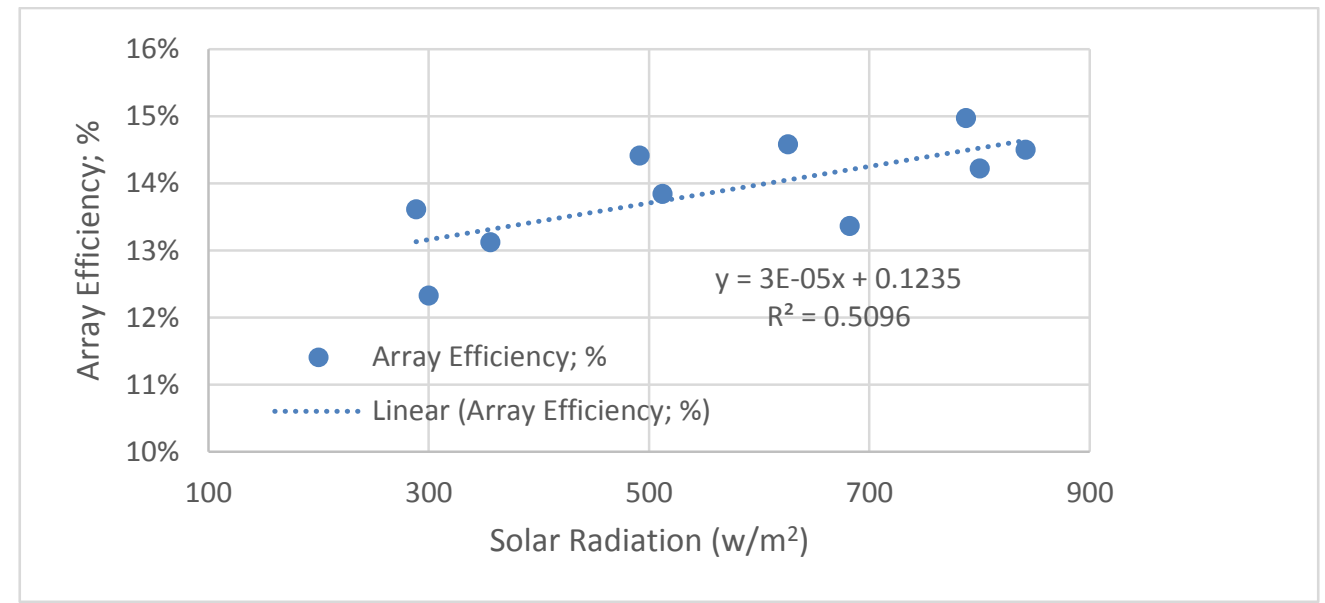

Fig. 11 Array efficiency averages at different values of solar radiation intensity.

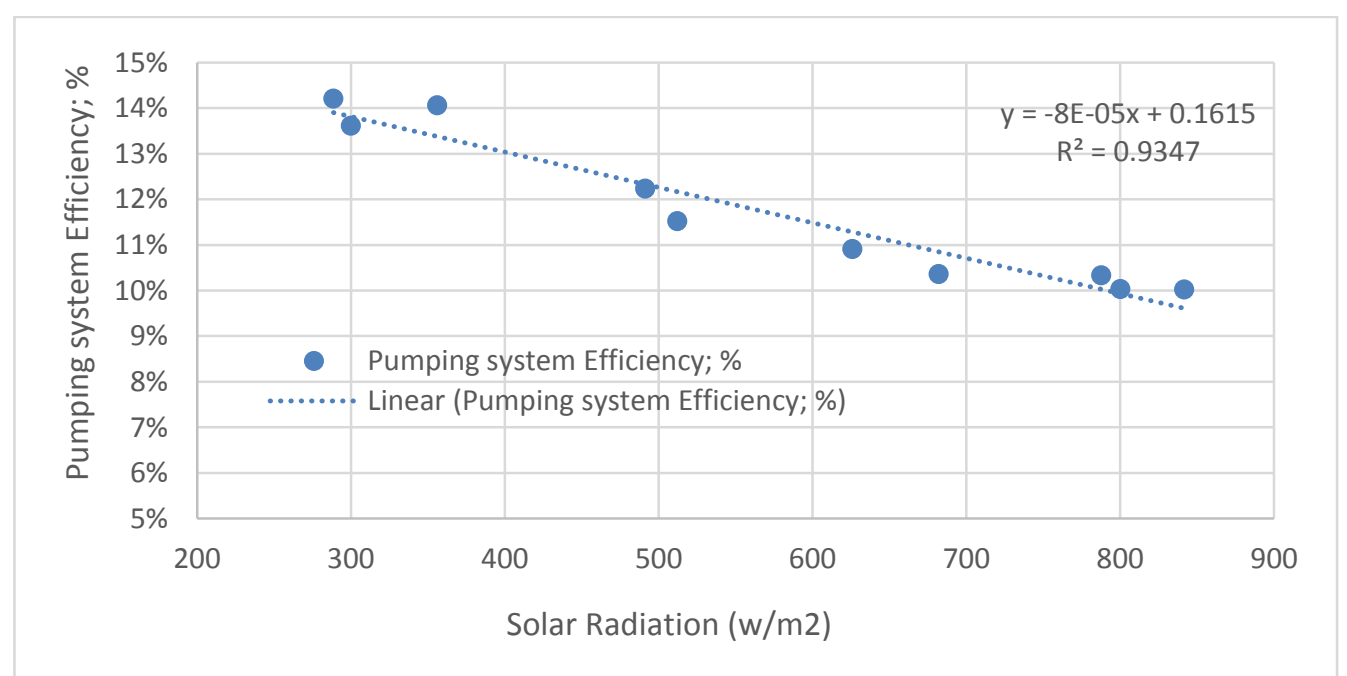

Fig. 12 shows pumping system efficiency average at deferent values of solar radiation intensity.

The results show that increase of the solar radiation duo to the decrease the subsystem efficiency.

The relationship between array efficiency and solar radiation was obtained in as following:

Where:

$$
y=-8^{\star} 10^{-5}+0.1615
$$

$\mathrm{Y}=$ Pumping system Efficiency and $\mathrm{X}=$ Solar Radiation $\left(\mathrm{w} / \mathrm{m}^{2}\right)$.

\section{Overall efficiency}

Fig. (13) shows the overall average efficiency of the system at different average solar radiation levels. The results show that the increase in the solar radiation duo to decrease the overall efficiency.

\section{SUMMARY AND CONCLUSION}

Solar radiation intensity variation during the day time influenced the output PV power that which affects the output hydraulic power and pumping rates relatively and the generated output electric power increases with increasing solar radiation intensity, ditto for the output hydraulic power. The highest solar radiation intensity was obtained at mid-day and when the solar radiation increase, the subsystem efficiency decreases. Performance of the solar photovoltaic pumping system found to be increased with increasing solar radiation intensity. It's highly recommended to use solar photovoltaic pumping system for small landscapes for the remote areas out of the grid and for the growing countries to reduce the burden on national subsidization for energy sources. 


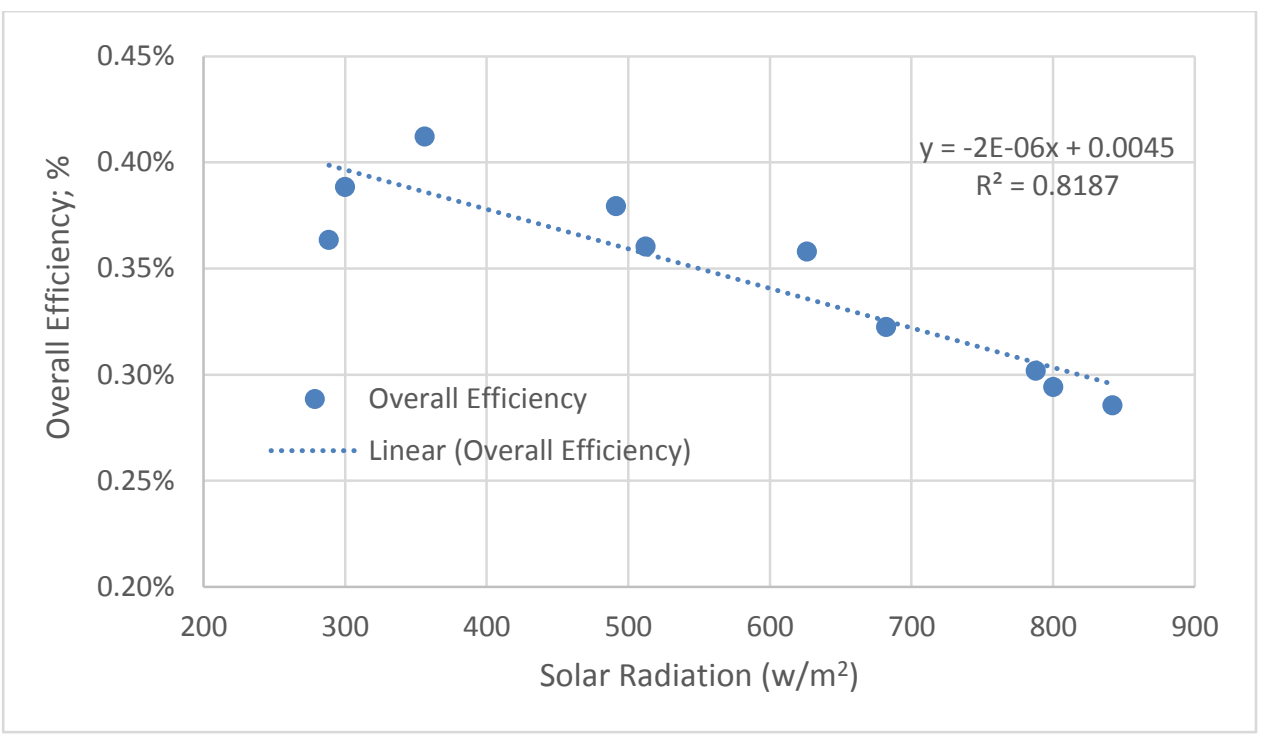

Fig. 13. Overall average efficiency of the system at different average solar radiation levels.

As an economic and environmental wise. Also, it's recommended to depend on the renewable energies and of course the solar energy particularly as an alternative for fossil fuels. Selection of system components plays a big role in the overall efficiency maximization. By selecting the matched system components, a high performance with maximum efficiency can be made.

In this respect a solar pumping systems were field tested in order to evaluate its performance under local working conditions.

The system comprised of three stages:

First stage: Generating DC power from PV cells.

Second stage: Converting DC power into mechanical power using DC motor.

Third stage: Converting mechanical power into hydraulic power using centrifugal pump.

The photovoltaic system was implemented consists of four modules $260 \mathrm{~W}$ each, manufacturer ALEO, model P18 polycrystalline. Panels were connected in parallel to give a $7.33 \mathrm{~A}$ and $138.4 \mathrm{~V}$ total to generate power for running DC motor pump system.

Measuring instruments were used to obtain data of the following parameters:

- The output voltage and current from the photovoltaic panels by digital electrical multimeter;

- Water flow rate from the pump by electronic flow meter;

- Water pressure from the pump by analog pressure gage;
The results showed that the maximum hydraulic output power was $14 \mathrm{~W}$ where the electrical power consumption was $140 \mathrm{~W}$ and the PV output power was $712 \mathrm{~W}$ at solar radiation intensity of 841 $\mathrm{W} / \mathrm{m}^{2}$. The maximum efficiency recorded for the overall system was $0.41 \%$ where the photovoltaic generator and pumping system efficiencies were $14.98 \%$ and $14.21 \%$ respectively.

\section{REFERENCES}

Carrasco, J.M., Franquelo, L.G., Bialasiewicz, J.T., Gal-van, E., Guisado, R.C.P., Prats, M.A.M., Leon, J.I. and Moreno-Alfonso, N. 2006. Power-electronic systems for thegrid integration of renewable energy sources: A survey. IEEE Transactions on Industrial Electronics, 53(4),1002- 1016.

Gawdat. B., 2013. Egypt's Energy Outlook: Opportunities and Challenges, Mediterranean Quarterly, 24, (1), 32-33.

Ghoneim A.A. 2006. Design optimization of photovoltaic powered water pumping systems. Energy Convers Manag, 47, 1449-1463.

Hamza, A. A. and Taha, A. Z. 1995. Performance of submersible PV solar pumping systems under conditions in the Sudan. Renewable energy, 6(5), 491-495.

Hsieh J.S. 1986. Solar energy engineering. New Jersey, Prantice Hall. pp. 73-81.

Kaldellis, J. K., Meidanis, E. and Zafirakis, D. 2011. Experimental energy analysis of a stand- 
of landscape system

alone photovoltaic-based water pumping installation. Applied Energy, 88(12), 4556-4562.

Kumar A., Kumar K., Kaushik N., Sharma S., Mishra S. 2010. Renewable energy in India: current status and future potentials. Renew Sustain Energy Rev, 14, 2434-2442.

Liserre, M., Sauter, T. and Hung, J.Y. 2010. Future energy systems: Integrating renewable energy sources into the smart power grid through industrial electronics. IEEE Industrial Electronics Magazine, 4(1), 18-37.

Mittal ML, Sharma, C. and Singh, R. 2012. Estimates of emissions from coal fired thermal power. plants in India. In: Proceedings of International Emission Inventory Conference; 1416 August. pp. 1-22.

Sorensen, B. 2003. Renewable Energy Its physics, engineering, use, environmental impacts, economy and planning aspects, Elsevier Academic Press, Roskilde Univ., Energy \& Environment Group, Denmark. 3, 121-129

Yüncü, H., Paykoc, E., and Yener, Y. 2012. Solar Energy Utilization: Fundamentals and Applications. Springer Science \& Business Media. 129, 91-98. 